\title{
PENGARUH PENGGUNAAN MEDIA PEMBELAJARAN AUDIO VISUAL GERAK TERHADAP MOTIVASI BELAJAR SISWA
}

\author{
Ilham Djafar' ${ }^{1)}$ Usman Moonti $^{2}$ Radia Hafid ${ }^{3}$ Aqil Bahsoan ${ }^{4)}$ \\ Jurusan Pendidikan Ekonomi, Fakultas Ekonomi, Universitas Negeri Gorontalo \\ Email : ilhamdjafar443@gmail.com
}

\begin{abstract}
ABSTRAK
Tujuan penelitian ini adalah untuk mengetahui seberapa besar pengaruh penggunaan media audio visual gerak pada IPS terpadu di kelas VIII ${ }^{1}$ SMP Negeri 1 Kota Gorontalo. Metode yang digunakan dalam penelitian ini adalah metode kuantitatif dengan jumlah sampel 36 siswa. Teknik pengolahan data dalam penelitian ini menggunakan regresi sederhana. Hasil Penelitian menunjukan bahwa Pemanfaatan Media Audio Visual Gerak berpengaruh positif terhadap Motivasi Belajar Siswa Kelas VIII ${ }^{1}$ SMP Negeri 1 Kota Gorontalo pada mata pelajaran IPS Terpadu. Besar pengaruh dari pemanfaatan media audio visual gerak terhadap motivasi belajar siswa mencapai $60.9 \%$ sedangkan sisanya sebesar $39.1 \%$ dipengaruhi oleh variabel yang tidak diteliti.
\end{abstract}

\section{Kata Kunci : Media Audio Visual Gerak, Motivasi Belajar}

\begin{abstract}
The purpose of this study is to find out the extent to which the use of motion graphic influence grade VII Students performance in an integrated social sciences subject. The study was conducted in junior high school SMPTN 1 Gorontalo.The sample of this quantitative research involved thirty six students. Further a simple linear regression analysis was used to analyze the date. The result show that the use of motion graphic media has appositive influence on the students learning motivation in an integtated social sciences subject. The percentage describing this outcome measure at $60,9 \%$. In addition, the remaining $39,1 \%$ refers to the percentage of other variables excluded from this study.
\end{abstract}

Keywords : Motion Graphic, Learning Motivation 


\section{PENDAHULUAN}

Media pembelajaran audio visual merupakan salah satu alat pembelajaran yang digunakan untuk mendorong peserta didik aktif dan berpartisipasi dalam proses pembelajaran. Pengertian media audio visual telah banyak dikemukakan oleh para ahli pendidikan. Sudjana dan Rivai (2003:58) mengemukakan bahwa media audio visual adalah sejumlah peralatan yang dipakai oleh para guru dalam menyampaikan konsep, gagasan dan pengalaman yang ditangkap oleh indera pandang dan pendengaran, berdasarkan pengertian yang telah diberikan maka media audio visual adalah media penyalur pesan dengan memanfaatkan indera pendengaran dan penglihatan. Tujuan penggunaan media pembelajaran audio visual guna merangsang peserta didik mengingat apa yang sudah dipelajari dan memberikan ransangan pelajaran baru serta mengaktifkan peserta didik sehingga dapat termotivasi dalam mengikuti proses pembelajaran.

Motivasi itu sendiri adalah dorongan yang timbul pada diri seseorang secara sadar atau tidak sadar untuk melakukan suatu tindakan dengan tujuan tertentu. Motivasi belajar menurut Uno (2007:23) yaitu sebagai dorongan internal dan eksternal pada siswa yang sedang belajar untuk mengadakan perubahan tingkah laku pada umumnya dengan beberapa indikasi atau unsur yang mendukung.

Dari penjelasan di atas bertolak belakang dengan hasil observasi yang dilakukan peneliti di SMP Negeri 1 Kota Gorontalo terutama pada proses mata pelajaran IPS Terpadu berlangsung. Fenomena ini menunjukan besarnya pengaruh media audio visual terhadap motivasi belajar siswa, hal ini dipengaruhi oleh beberapa aspek yaitu rendahnya motivasi belajar siswa dalam mengikuti pembelajaran, pada saat proses pembelajaran ada beberapa siswa yang mengantuk bahkan sampai tertidur dalam kelas, saat pembelajaran berlangsung siswa cenderung pasif dalam belajar, siswa tidak mau bertanya dan belum ada keberanian untuk menjawab pertanyaan yang diberikan oleh guru, saat guru menjelaskan materi siswa hanya asik berbicara dengan teman sebangku, sehingga menimbulkan kegaduhan dan pembelajaran di kelas menjadi tidak kondusif, dengan masalah yang ada, maka guru menggunakan media audio visual untuk meningkatkan motivasi belajar siswa pada mata pelajaran IPS dikelas VIII ${ }^{1}$ dengan jumlah 36 siswa. Dari jumlah tersebut banyak siswa yang kurang tertarik dan merasa bosan akibat proses pembelajaran yang monoton. Waktu penggunaan media audio visual yang dilakukanpun tidak mendapat respon yang sangat positif, karena realitanya harapan yang di maksud belum dapat terpenuhi. 


\section{KAJIAN TEORI}

\section{A. Pengertian Motivasi Belajar}

Motivasi belajar adalah dorongan dari proses belajar dan tujuan dari belajar adalah mendapatkan manfaat dari proses belajar. Beberapa siswa mengalami masalah dalam belajar yang berakibat prestasi belajar tidak sesuai dengan yang diharapkan. Untuk mengatasi masalah yang dialami tersebut perlu ditelusuri faktor yang mempengaruhi hasil belajar diantaranya adalah motivasi belajar siswa, dimana motivasi belajar merupakan syarat mutlak untuk belajar, serta sangat memberikan pengaruh besar dalam memberikan gairah atau semangat dalam belajar. (Puspitasari, 2012).

Pengertian motivasi belajar menurut Uno (2007 : 23) yaitu memberikan batasan mengenai motivasi belajar siswa sebagai "Dorongan internal dan eksternal pada siswa yang sedang belajar untuk mengadakan perubahan tingkah laku pada umumnya dengan beberapa indikasi atau unsur yang mendukung".

Winkel (2012) mendefinisikan bahwa motivasi belajar adalah segala usaha di dalam diri sendiri yang menimbulkan kegiatan belajar, dan menjamin kelangsungan dari kegiatan belajar serta memberi arah pada kegiatan-kegiatan belajar sehingga tujuan yang dikehendaki tercapai. Motivasi belajar merupakan faktor psikis yang bersifat non intelektual dan berperan dalam menumbuhkan semangat belajar untuk individu.

\section{B. Ciri-ciri Motivasi Belajar}

Sardiman (2011 : 53), mengemukakan bahwa ciri-ciri motivasi yang ada pada diri sendiri adalah :

1. Tekun dalam menghadapi tugas atau dapat bekerja secara terus-menerus dalam waktu lama.

2. Ulet dalam menghadapi kesulitan dan tidak mudah putus asa

3. Menunjukan minat yang besar terhadap bermacam-macam masalah besar

4. Lebih suka bekerja sendiri dan tidak bergantung kepada orang lain

5. Tidak cepat bosan dengan tugas-tugas rutin

6. Dapat mempertahankan pendapatnya

7. Tidak mudah melepaskan apa yang diyakini, senang mencari dan memecahkan masalah

\section{Fungsi Motivasi Belajar}

Fungsi motivasi dalam belajar bertalian dengan suatu tujuan. Sardiman (dalam Anggrian :2011, 35-36) menyatakan bahwa ada tiga fungsi motivasi, yaitu :

a) Mendorong manusia untuk berbuat, jadi sebagai penggerak atau motor yang melepaskan energy

b) Menentukan arah perbuatan, yakni tujuan yang hendak dicapai. Dengan demikian motivasi dapat memberikan arah kegiatan yang harus dikerjakan sesuai dengan rumusan tujuannya 
c) Menyeleksi perbuatan, yakni menentukan perbuatan-perbuatan apa yang harus dikerjakan yang serasi guna mencapai tujuan, dengan menyisihkan perbuatan-perbuatan yang tidak bermanfaat.

\section{Pengertian Media Audio Visual Gerak}

Sudjana dan Rivai (2003:58) mengemukakan bahwa media audio visual adalah sejumlah peralatan yang dipakai oleh para guru dalam menyampaikan konsep, gagasan dan pengalaman yang ditangkap oleh indera pandang dan pendengara berdasarkan pengertian-pengertian yang telah diberikan, maka media audio visual adalah media penyalur pesan dengan memanfaatkan indera pendengaran dan penglihatan.

Menurut (Hermawan, 2007) mengemukakan bahwa "Media Audio Visual adalah media intruksional modern yang sesuai dengan perkembangan zaman (kemajuan ilmu pengetahuan dan teknologi) meliputi media yang dapat dilihat dan didengar.

Media audio visual gerak adalah media intruksional modern yang sesuai dengan perkembangan zaman (kemajuan ilmu pengetahuan dan teknologi) karena meliputi penglihatan, pendengaran dan gerakan, serta menampilkan unsur gambar yang bergerak. Jenis media yang termasuk dalam kelompok ini adalah televisi, video tape, dan film bergerak.

\section{E. Jenis-Jenis Media Audio Visual Gerak}

1. Film

Film atau gambar hidup merupakan gambar-gambar dalam frame dimana frame demi frame diproyeksikan melalui lensa proyektor secara mekanis sehingga pada layar terlihat gambar itu hidup.

Kemampuan film melukiskan gambar hidup dan suara memberinya daya tarik tersendiri. Kedua jenis media ini pada umumnya digunakan untuk tujuan-tujuan hiburan, dokumentasi, dan pendidikan. Mereka dapat menyajikan informasi, memaparkan proses, menjelaskan konsep-konsep yang rumit, mengajarkan keterampilan, menyingkat atau memperpanjang waktu, dan mempengaruhi sikap.

Oemar Hamalik mengemukakan bahwa film yang baik mamiliki ciri-ciri sebagi berikut:

a) Dapat menarik minat anak

b) Benar dan autentik

c) Up to date dalam setting, pakaian dan lingkungan

d) Sesuai dengan tingkatan kematangan audien

e) Perbendaharaan bahasa yang dipergunakan secara benar

f) Kesatuan dan squence-nya cukup teratur

g) Teknis yang dipergunakan cukup memenuhi persyaratan dan cukup memuaskan. 


\section{Video}

Video sebagai media audio visual yang menampilkan gerak, semakin lama semakin populer dalam masyarakat kita. Pesan yang disajikan dapat bersifat fakta (kejadian/ peristiwa penting, berita), maupun fiktif (seperti misalnya cerita), bisa bersifat informatif, edukatif maupun intruksional. Sebagian besar tugas film dapat digantikan oleh video, namun tidak berarti bahwa video akan menggantikan kedudukan film. Masing-masing memiliki keterbatasan dan kelebihan sendiri.

3. Televisi (TV)

Televisi adalah sistem elektronik yang mengirimkan gambar diam dan gambar hidup bersama suara melalui kabel dan ruang. Dewasa ini televisi yang dimanfaatkan untuk keperluan pendidikan dengan mudah dapat dijangkau melalui siaran dari udara ke udara dan dapat dihubungkan melalui satelit.

\section{III.METODE PENELITIAN}

Sugiyono (2018:7) penelitian ini menggunakan pendekatan kuantitatif, pendekatan kuantitatif didasari oleh positivisme yang memandang setiap realitas/fenomena itu dapat di klasifikasikan, relative tetap, konkrit, teramati, terukur, dan hubungan gejala bersifat sebab akibat. Proses penelitian ini di lakukan dari "luar" dengan menggunakan pengukuran disertai analisis secara statistik sehingga penelitian mengimplikasikan, bahwa pendekatan ini menggunakan metode kuantitatif.

Sugiyono (2018:215) mengemukakan bahwa sampel adalah sebagian dari populasi itu. Populasi itu misalnya penduduk di wilayah tertentu, jumlah pegawai pada organisasi tertentu, jumlah guru dan murid di sekolah tertentu dan sebagainya.

Berdasarkan pendapat diatas teknik pengambilan sampel yang digunakan dalam penelitian ini yaitu Simple Purposive. Sampel purposive adalah teknik penentuan sample dengan pertimbangan tertentu yang dianggap paling tahu tentang apa yang kita harapkan (Sugiyono, 2018:219). Dari pernyataan di atas maka sampel dalam penelitian ini sebanyak 36 siswa.

Teknik pengumpulan data yang digunakan adalah angket, observasi, dan dokumentasi. Sedangkan teknik pengujian menggunakan uji validitas dan reliabilitas, normalitas dan regresi.

\section{A. Uji Validitas Dan Reliabilitas}

1. Uji Validitas

Perhitungan koefisien validitas dilakukan dengan menggunakan rumus Korelasi Produk Moment, yakni :

$r x y=\frac{n \Sigma x y-(\Sigma x)(\Sigma y)}{\sqrt{\left\{n \Sigma x^{2}\right\}\left\{n \Sigma y^{2-(\Sigma Y)^{2}}\right\}}}$

(Sugiyono, 2018 : 183) 
Di mana :

$r x y=$ koefisien korelasi product moment

$\Sigma x=$ skor untuk setiap item

$\Sigma y=$ skor total untuk seluruhan item

$\mathrm{n}=$ jumlah responden

\section{Reliabilitas}

Reliabilitas menunjukan pada suatu pengertian bahwa mutu suatu instrumen cukup dapat dipercaya untuk digunakan sebagai alat pengumpul data karena instrument tersebut sudah baik (Arikunto, 2016:178). Pada penelitian ini pengujian uji reliabilitas dilakukan dengan menggunakan metode Alpha yaitu dengan menganalisis reliabilitas alat ukur dari satu kali pengukuran. Untuk mencari reliabilitas digunakan rumus Alpha :

$$
\begin{aligned}
& \text { Rumus Alpha } \\
& r_{11}=\left\{\frac{k}{k-1}\right\}\left\{1 \frac{\Sigma \sigma_{\frac{b}{b}}}{\sigma \frac{2}{1}}\right\} \quad \text { (Arikunto, 2013:239) } \\
& \quad \text { di mana : } \\
& r_{11}=\text { Reliabilitas } \\
& k=\text { Banyak butir pertanyaan atau banyaknya soal } \\
& \sum \sigma \frac{2}{b}=\text { Jumlah varian butir } \\
& \sigma \frac{2}{1}=\text { varian total }
\end{aligned}
$$

\section{B. Uji Linearitas}

Untuk mengetahui hubungan linearitas menggunakian rumus seperti yang dikemukakan oleh Hadi (2014) sebagai berikut :

Ket :

$$
F_{\text {reg }}=\frac{\text { RKreg }}{\text { RKres }}
$$

$\mathrm{F}_{\text {reg }}=$ Harga $\mathrm{F}$ untuk garis regresi

$\mathrm{RK}_{\text {reg }}=$ Rerata kuadrat garis regresi

$\mathrm{RK}_{\text {res }}=$ Rerata kuadrat residu

Selanjutnya harga $\mathrm{F}$ hitung dikonsultasikan dengan harga pada $\mathrm{F}$ tabel dengan taraf signifikan 5\%. Jika F hitung yang diperoleh lebih kecil dari F tabel maka kedua variabel mempunyai pengaruh linear. Sebaliknya, jika harga $F$ hitung lebih besar dari $\mathrm{F}$ tabel berarti kedua variabel mempunyai pengaruh yang tidak linear.

\section{Teknik Analisis Data}

Teknik analisis data di gunakan dalam penelitian ini adalah regresi linier sederhana. Persamaan umum regresi linier sederhana adalah :

$$
\hat{\mathbf{Y}}=\mathbf{a}+\mathbf{b X} \quad \text { (Sugiyono, 2018:188) }
$$




\section{Dimana :}

$\hat{\mathrm{Y}} \quad=$ subjek dalam variabel terkait yang diprediksikan

a = konstanta atau bila harga $\mathrm{x}-0$

$\mathrm{b} \quad=$ koefisien regresi atau angka yang menunjukan peningkatan ataupun penurunan variabel dependen yang didasarkan pada perubahan variabel independen

$\mathrm{X} \quad=$ subjek pada variabel independen yang mempunyai nilai tertentu Harga a dan b melalui rumus sebagai berikut :

$$
\begin{array}{r}
\mathrm{a}=\frac{\left(\sum Y\right)\left(\sum \mathrm{x} \mathbf{2}\right)-\left(\sum y\right)\left(\sum x y\right)}{n \sum \mathbf{x} \mathbf{2}-\left(\sum \mathbf{x}\right) \mathbf{2}} \text { (Sugiyono, 2018:262) } \\
\mathrm{b}=\mathrm{n}=\frac{\left(\sum Y\right)\left(\sum \mathbf{x} 2\right)-\left(\sum y\right)\left(\sum x y\right)}{n \sum \mathbf{x} 2-\left(\sum \mathbf{x}\right) \mathbf{2}}
\end{array}
$$

\section{Uji Normalitas}

Uji normalitas digunakan untuk memenuhi apakah populasi yang diambil dalam penelitian ini berasal dari proposal berdistribusi normal atau tidak normal. Apabila hasil pengujian normal, maka perhitungan statistik pada penelitian ini dapat digeneralisasikan pada populasi. Uji normalitas ini menggunakan rumus chi kuadrat $\left(\mathrm{X}^{2}\right)$ sesuai dengan pendapat Ridwan (2011:132) yang mengatakan bahwa metode chi kuadrat $\left(\mathrm{X}^{2}\right)$ digunakan untuk mengadakan pendekatan (mangestimate) dari beberapa factor atau mengevaluasi frekuensi yang diharapkan (fe) dari sampel apakah terdapat hubungan atau perbedaan yang signifikan atau tidak. Rumus chi kuadrat tersebut sebagai berikut :

$$
\mathrm{X}^{2}=\sum \mathrm{k}_{\mathrm{i}=1} \frac{(f o-f e)^{2}}{f e}
$$

Dimana :

$\mathrm{X}^{2} \quad=$ Chi Kuadrat

Fo $\quad=$ Frekuensi Observasi Sampel

$\mathrm{Fe} \quad=$ Frekuensi yang Diharapkan

Apabila hasil chi kuadrat yang diperoleh melalui perhitungan $\left(\mathrm{X}^{2}\right.$ hitung) lebih kecil daripada harga chi kuadrat pada table $\left(\mathrm{X}^{2}\right.$ tabel) dengan taraf signifikan 5\% maka data dari variabel tersebut berdistribusi normal. Sebaliknya jika harga chi kuadrat dihitung lebih besar daripada chi kuadrat table maka data variabel tersebut berdistribusikan tidak normal.

\section{E. Hipotesis Statistik}

Untuk kepentingan pengujian hipotesis secara statistik, maka hipotesis penelitian di atas di tetapkan dalam hipotesis statistik sebagai berikut :

Ho : $\beta \leq o=$ Tidak terdapat pengaruh penggunaan media pembelajaran audio visual gerak terhadap motivasi belajar siswa 
$H a: \beta>o=$ Terdapat pengaruh penggunaan media pembelajaran audio visual gerak terhadap motivasi belajar siswa

\section{IV.HASIL DAN PEMBAHASAN}

\section{A. Hasil Pengujian Validitas Dan Reliabilitas Kuesioner}

1. Variabel Media Pembelajaran Audio Visual Gerak

Hasil analisis data menunjukkan bahwa dari segi ketepatan dalam mengukur 13 pertanyaan yang digunakan dalam mengukur Penggunaan Media Audio Visual Gerak. Seluruh pertanyaan telah memiliki ketepatan yang baik. Adapun hasil pengujian reliabilitas untuk variabel disiplin adalah sebagai berikut :

\begin{tabular}{|c|c|c|c|c|}
\hline Variabel & $\begin{array}{c}\text { No } \\
\text { Item }\end{array}$ & r-Hitung & r-Tabel & Keterangan \\
\hline \multirow{13}{*}{$\begin{array}{l}\text { Media Audio } \\
\text { Visual Gerak }\end{array}$} & 1 & 0.483 & \multirow{13}{*}{0,3} & Valid \\
\hline & 2 & 0.525 & & Valid \\
\hline & 3 & 0.705 & & Valid \\
\hline & 4 & 0.659 & & Valid \\
\hline & 5 & 0.513 & & Valid \\
\hline & 6 & 0.477 & & Valid \\
\hline & 7 & 0.747 & & Valid \\
\hline & 8 & 0.611 & & Valid \\
\hline & 9 & 0.652 & & Valid \\
\hline & 10 & 0.560 & & Valid \\
\hline & 11 & 0.612 & & Valid \\
\hline & 12 & 0.403 & & Valid \\
\hline & 13 & 0.510 & & Valid \\
\hline
\end{tabular}

\section{Reliability Statistics}

\begin{tabular}{cc}
\hline Cronbach's Alpha & N of Items \\
\hline 0.831 & 13 \\
\hline
\end{tabular}

\section{Variabel Motivasi Belajar}

Hasil analisis data di atas menunjukkan bahwa dari segi ketepatan dalam mengukur 17 pertanyaan yang digunakan dalam mengukur motivasi belajar siswa. Seluruh pertanyaan telah memiliki ketapatan yang baik. Adapun hasil pengujian reliabilitas untuk variabel motivasi belajar siswa adalah sebagai berikut: 


\begin{tabular}{|c|c|c|c|c|}
\hline Variabel & $\begin{array}{c}\text { No } \\
\text { Item }\end{array}$ & r-Hitung & r-Tabel & Keterangan \\
\hline \multirow{17}{*}{$\begin{array}{c}\text { Motivasi Belajar } \\
\text { Siswa }\end{array}$} & 1 & 0.718 & \multirow{17}{*}{0,3} & Valid \\
\hline & 2 & 0.710 & & Valid \\
\hline & 3 & 0.486 & & Valid \\
\hline & 4 & 0.416 & & Valid \\
\hline & 5 & 0.489 & & Valid \\
\hline & 6 & 0.500 & & Valid \\
\hline & 7 & 0.633 & & Valid \\
\hline & 8 & 0.357 & & Valid \\
\hline & 9 & 0.478 & & Valid \\
\hline & 10 & 0.524 & & Valid \\
\hline & 11 & 0.472 & & Valid \\
\hline & 12 & 0.340 & & Valid \\
\hline & 13 & 0.481 & & Valid \\
\hline & 14 & 0.547 & & Valid \\
\hline & 15 & 0.533 & & Valid \\
\hline & 16 & 0.390 & & Valid \\
\hline & 17 & 0.479 & & Valid \\
\hline
\end{tabular}

\section{Reliability Statistics}

\begin{tabular}{c|c}
\hline Cronbach's Alpha & N of Items \\
0.814 & 17 \\
\hline
\end{tabular}

\section{B. Pengujian Normalitas Data}

Hasil pengujian normalits pada table di bawah, diperoleh hasil Kolmogorov-Smirnov Z sebesar 0.827 dengan nilai asymp. Sig. (2-tailed) atau probabilitas sebesar 0.501 yang berada diatas 0.05 seperti yang telah disyaratkan. Dengan demikian dapat disimpulkan bahwa data dalam penelitian ini berdistribusi normal. 


\section{One-Sample Kolmogorov-Smirnov Test}

\begin{tabular}{llr}
\hline & & \multicolumn{2}{c}{$\begin{array}{c}\text { Unstandardized } \\
\text { Residual }\end{array}$} \\
\hline $\mathrm{N}$ & \multicolumn{1}{c}{ Mean } & 36 \\
\cline { 2 - 3 } & Std. Deviation & .0000000 \\
\hline Mormal Parameters ${ }^{\mathrm{a}, \mathrm{b}}$ & Absolute & .138 \\
\cline { 2 - 3 } & Positive & .138 \\
\cline { 2 - 3 } & Negative & -.090 \\
\hline Kolmogorov-Smirnov Z & & .827 \\
\hline Asymp. Sig. (2-tailed) & & .501 \\
\hline a. Test distribution is Normal. & & \\
\hline b. Calculated from data. & & \\
\hline
\end{tabular}

C. Pengujian Model Regresi Secara Keseluruhan

\begin{tabular}{lllrrrr}
\hline \multicolumn{7}{c}{ ANOVA $^{\mathbf{b}}$} \\
\hline \multirow{2}{*}{ Model } & $\begin{array}{l}\text { Sum of } \\
\text { Squares }\end{array}$ & \multicolumn{1}{c}{ df } & \multicolumn{1}{c}{ Mean } \\
Square & \multicolumn{1}{c}{ F } & \multicolumn{1}{c}{ Sig. } \\
\hline \multirow{2}{*}{1} & Regression & 1730.637 & 1 & 1730.637 & 53.005 & $.000^{\mathbf{a}}$ \\
\cline { 2 - 7 } & Residual & 1110.113 & 34 & 32.650 & & \\
\cline { 2 - 7 } & Total & 2840.750 & 35 & & & \\
\hline
\end{tabular}

a. Predictors: (Constant), Media Audio Visual Gerak

b. Dependent Variable: Motivasi Belajar

Dari hasil analisis diatas dapat di ketahui nilai F-hitung sebesar 53.005 dengan nilai signifikansi sebesar 0.000. Sementara nilai F-tabel pada tingkat kepercayaan $5 \%$ dan derajat bebas df $1=1$ dan df $2=n-k=36-2=34$ adalah sebesar 4.13. Jika kedua nilai $F$ ini dibandingkan dengan nilai $F$ hitung yang diperoleh jauh lebih besar dari nilai F-tabel maka $\mathrm{H}_{0}$ ditolak. Dengan demikian dapat disimpulkan bahwa model regresi yang dibangun sesuai dengan data. 
D. Pengujian Pengaruh Penggunaan Media Audio Visual Gerak Terhadap Motivasi Belajar Siswa

\begin{tabular}{|c|c|c|c|c|c|}
\hline \multicolumn{6}{|c|}{ Coefficients $^{\mathrm{a}}$} \\
\hline \multirow{2}{*}{ Model } & $\begin{array}{r}\text { Unstan } \\
\text { Coef }\end{array}$ & $\begin{array}{l}\text { ardized } \\
\text { cients }\end{array}$ & $\begin{array}{l}\text { Standardized } \\
\text { Coefficients }\end{array}$ & \multirow{2}{*}{$\mathrm{t}$} & \multirow{2}{*}{ Sig. } \\
\hline & B & Std. Error & Beta & & \\
\hline (Constant) & 24.296 & 5.547 & & 4.380 & .000 \\
\hline $\begin{array}{l}\text { Media Audio Visual } \\
\text { Gerak }\end{array}$ & .842 & .116 & .781 & 7.280 & .000 \\
\hline
\end{tabular}

a. Dependent Variable: Motivasi Belajar

Dari hasil analisis diatas dapat dilihat nilai t-tabel yang diperoleh untuk variabel media audio visual gerak adalah sebesar 7.280. Untuk mendapatkan kesimpulan apakah menerima atau menolak Ho, terlebih dahulu harus ditentukan nilai t-tabel yang akan digunakan. Dengan menggunakan tingkat signifikansi sebesar 5\% dan nilai df sebesar $\mathrm{n}-\mathrm{k}-1=36-1-1=34$ diperoleh nilai t-tabel sebesar 2.030. Jika dibandingkan dengan nilai thitung yang diperoleh sebesar 7.280 maka nilai t-hitung yang diperoleh masih lebih besar dari nilai t-tabel sehingga Ho ditolak. Dengan demikian pada tingkat kepercayaan $95 \%$ dapat disimpulkan bahwa terdapat pengaruh yang positif dan signifikan dari penggunaan media audio visual gerak terhadap motivasi belajar siswa.

\section{E. Penafsiran Koefisien Determinasi}

\begin{tabular}{lrrrr}
\hline \multicolumn{4}{c}{ Model Summary $^{\mathbf{b}}$} \\
\hline Model & $\mathrm{R}$ & R Square & Adjusted R Square & $\begin{array}{c}\text { Std. Error of the } \\
\text { Estimate }\end{array}$ \\
\hline 1 & $.781^{\mathrm{a}}$ & .609 & .598 & 5.714 \\
\hline a. Predictors: (Constant), Media Audio Visual Gerak & \\
\hline
\end{tabular}

Dari analisis diatas terlihat nilai koefisien determinasi dari model regresi yang telah diperoleh sebelumnya sebesar 0.609. Nilai ini berarti bahwa sebesar $60.9 \%$ variasi motivasi belajar siswa dikelas VIII ${ }^{1}$ SMP Negeri 1 Kota Gorontalo di jelaskan oleh penggunaan media audio visual gerak yang diterapkan. Dengan kata lain semakin baik penggunaan media audio visual gerak yang diterapkan maka motivasi belajar siswa juga akan semakin baik.

\section{F. Pembahasan}

Motivasi adalah sesuatu yang dapat mempengaruhi atau mendorong seseorang yang merupakan energi pada diri seseorang untuk mencapai tujuan yang diharapkan. Motivasi dapat pula dikatakan serangkaian usaha untuk menyediakan 
kondisi-kondisi tertentu, sehingga seseorang itu mau dan ingin melaakukan sesuatu dan bila ia tidak suka, maka akan beusaha untuk meniadakan atau mengelakkan perasaan tidak suka itu. Jadi, motivasi itu dapat dirancang dari luar tetapi motivasi itu dalah tumbuh di dalam diri seseorang.

Media audio visual gerak adalah media yang mempunyai unsur suara dan unsur gambar. Jenis media ini mempunyai kemampuan yang lebih baik, karena meliputi kedua jenis media auditif (mendengar) dan visual (melihat). Media Audio visual gerak merupakan sebuah alat bantu audio visual yang berarti bahan atau alat yang dipergunakan dalam situasi belajar untuk membantu tulisan dan kata yang diucapkan dalam menularkan pengetahuan, sikap, dan ide.

Hasil analisis yang telah dilakukan menunjukkan pengaruh yang signifikan dari penggunaan media audio visual gerak terhadap motivasi belajar siswa. Hal ini berdasarkan pada hasil pengujian F-hitung untuk variabel penggunaan media audio visual gerak yang lebih besar dari F-tabel sehingga $\mathrm{H}_{0}$ ditolak. Ini menunjukkan bahwa sedikit atau banyaknya penggunaan media audio visual gerak di sekolah dapat mempengaruhi motivasi belajar siswa. Motivasi belajar siswa adalah sebagai terjadinya perhatian, ketertarikan dan rasa senang pada setiap peserta didik.

Sehubungan dengan penelitian ini adalah untuk mengetahui pengaruh penggunaan media audi visual gerak terhadap motivasi belajar siswa di SMP Negeri 1 Kota Gorontalo. Hasil pengujian hipotesis dengan menggunakan pengujian regresi linear sederhana, dari hasil perhitungan diperoleh persamaan regresi dan signifikan.

Selanjutnya dari hasil penelitian yang telah dijelaskan sebelumnya menunjukkan bahwa ternyata ada pengaruh antara penggunaan media audio visual gerak terhadap motivasi belajar siswa di SMP Negeri 1 Kota Gorontalo. Motivasi belajar dapat meningkatkan sikap juga akademik tertentu yang bersifat sangat pribadi pada setiap siswa. Oleh karena itu siswa membutuhkan motivasi belajar atau dorongan dari proses belajar dan tujuan dari belajar guna mendapatkan manfaat dari proses belajar.

Koefisien regresi yang bertanda positif dari variabel dukungan menunjukkan bahwa peningkatan penggunaan media audi visual gerak akan meningkat motivasi belajar siswa. Hal ini disebabkan dengan semakin baik penggunaanya media audio visual gerak akan menarik perhatian juga membuat seorang peserta didik termotivas, sehingga hal ini dapat mempermudah proses pembelajaran yang sedang berlangsung. Siswa akan lebih mudah memahami materi sekaligus akan membantu dalam proses belajar. Dimana siswa akan menjadi aktif dalam pembelajaran karena memperoleh informasi baru.

Hasil penelitian ini sejalan dengan penelitian yang diteliti oleh Widia Nengsih (2016) dengan judul pengaruh penggunaan media audio visual terhadap hasil belajar matematika peserta didik kelas 5 SDN 3 sawah lama Bandar Lampung, yang menunjukan pengaruh positif dan signifikan sebesar $54.6 \%$. 
Berdasarkan hasil penelitian yang dilakukan, maka diperoleh pengaruh penggunaan media audio visual gerak terhadap motivasi belajar siswa pada mata pelajaran IPS Terpadu di kelas VIII ${ }^{1}$ SMP Negeri 1 Kota Gorontalo ditunjukkan oleh nilai koefisien determinasi sebesar $60.9 \%$. Dengan demikian sisanya $39.1 \%$ dipengaruhi oleh variabel lain yang tidak diteliti.

\section{KESIMPULAN}

Dari penelitian analisis yang telah dilakukan maka peneliti mengambil kesimpulan bahwa, terdapat pengaruh yang positif dari penggunaan media audio visual gerak terhadap motivasi belajar siswa. Semakin sering penggunaan media pembelajaran audio visual gerak, maka akan meningkatkan motivasi belajar siswa.

Penggunaan media audio visual gerak terhadap motivasi belajar siswa mencapai $60.9 \%$ sedangkan sisanya sebesar $39.1 \%$ dipengaruhi oleh variabel lain yang tidak diteliti.

\section{DAFTAR PUSTAKA}

Aang Kurniawan. 2015. Pengaruh Penggunaan Media Pembelajaran Visual Terhadap Hasil Belajar Ekonimi Siswa Kelas X Semester Genap SMA Negeri 1 Pekalongan. [skripsi]. Surakarta (ID) : Universitas Sebelas Maret.

Arikunto, S. (2013). "Prosedur Penelitian Suatu Pendekatan Praktik”. Jakarta : Rineka Cipta.

Hanafiah. (2012). “Konsep Strategi Pembelajaran”. Bandung : Rafika Aditama

Hermawan. (2007). “Media Pembelajaran SD”. Bandung : Upi Press.

Herminarto dan Uno, Hamzah.(2007). "Teori Motivasi Dan Aplikasinya Dalam Peneletian". Gorontalo Nurul Jannah.

Isriani H. dan Dewi Puspitasari. (2012). "Strategi Pembelajaran Terpadu". Yogyakarta : FAMILIA.

Munanadi, Yudhi. (2013). "Media Pembelajaran Sebuah Pendekatan Baru". Jakarta : Gaung Persada Press Group.

Oemar, Hamalik. (2009). "Media Pendidikan". Bandung : Pustaka Martiana

Sardiman , (2012). "Interaksi \& Motivasi Belajar Mengajar”. Jakarta : Raja Grafindo Persada.

Sudjana \& Rivai. (2003). “Media Pengajaran”. Bandung : Sinar Baru Algesindo Offset.

Sugiyono. (2018). Metode Penelitian Kuantitatif, Kualitatif Dan R\&D. Bandung : Alfabeta. 
Suryani, Nunuk dan Leo Agung. (2012). "Strategi Belajar Mengajar”. Yogyakarta : Ombak.

Uno, Hamza B. (2007). "Teori Motivasi dan Pengukurannya". Jakarta : Bumi Aksara.

Widia Nengsih. 2018. Pengaruh Penggunaan Media Visual Terhadap Hasil Belajar Matematika Peserta Didik Kelas V SDN Sawah Lama Bandar Lampung. [skripsi]. Bandar Lampung (ID) : Universitas Lampung.

Winkel. (2012). “Psikologi Pengajaran”. Yogyakarta : Media Abadi

Yusuf, Syamsu. (2009). "Program Bimbingan \& Konseling di Sekolah”. Bandung : Rizki Press 